Research Article

\title{
Screening, Isolation and Biochemical Characterization of Laccase Producing Bacteria from Contaminated Sites
}

\author{
J. Siva Jyothi ${ }^{* 1}$, K. Kishore Kumar ${ }^{2}$, E. Hema Latha ${ }^{3}$ \\ ${ }^{1}$ Assistant Professor, Department of Pharmaceutical Biotechnology, Hindu College of Pharmacy, Amaravathi Road, Guntur-522002, \\ Andhra Pradesh, India. \\ 2 Narayana Pharmacy College, Chintareddy Palem, Nellore, JNTUA, Ananthapuramu - 524002, Andhra Pradesh, India. \\ ${ }^{3}$ Sri Vishnu College of Pharmacy, Bhimavaram - 534202, Andhra Pradesh, India. \\ *Corresponding author's E-mail: jsjbiotech81@gmail.com
}

Received: 18-09-2021; Revised: 24-11-2021; Accepted: 30-11-2021; Published on: 20-12-2021.

\begin{abstract}
Screening and isolation of Laccase producing bacteria from Guntur District soil was carried out to assess the diversity of Lignocellulose degrading bacteria. Isolation and identification of environmental friendly bacteria for lignin degradation becomes an essential one, because all the researchers are mainly concentrating on fungal strains. However, bacteria seem to play a leading role in decomposing lignin. For isolation of Laccase producing bacteria nutrient agar medium containing guaiacol was used. Total nine bacterial strains were isolated from soil samples collected from different regions of Guntur district. Preliminary screening of bacterial strains was carried out on guaiacol containing nutrient agar medium for laccase production. Formation of green colour using ABTS (2,2'azinobis(3-ethylbenzthiazoline-6-sulfonate) confirms the capability of laccase production by the bacterial strains. Nine bacterial strains showed positive results. High laccase producing bacterial isolates were examined for morphological and biochemical characteristics according to Bergey's Manual of Systematic Bacteriology. The predominant isolates were identified as Bacillus and Enterobacter species.
\end{abstract}

Keywords: Lignin degrading bacteria, ABTS, Laccase, Guaiacol, Nutrient agar medium.

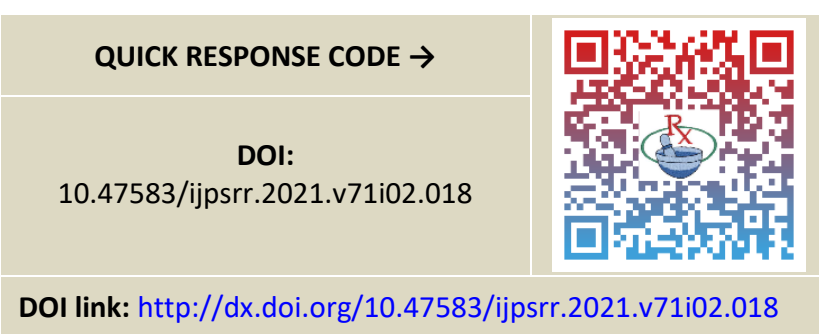

\section{INTRODUCTION}

accases (Benzenediol: oxygen oxidoreductases; EC 1.10.3.2) are a versatile oxidoreductase enzymes, are also called as "BLUE ENZYMES" because they are multinuclear copper containing enzymes. ${ }^{1}$ Laccases are having the capability to oxidize a wide range of phenolic and nonphenolic compounds by converting oxygen molecule to water on concomitant four-electron reduction. $^{2}$

Laccases are abundantly present in various fungi and higher plants. It is mainly produced from fungi, especially white rot, and has been extensively exploited for the application in industrial processes due to their high redox potential.

The commercial production of fungal laccases is usually hindered due to high fermentation period, low laccase yield and also their applicability only under mesophilic and acidic reaction condition. Majority of the industrial operations are carried out in extreme conditions, i.e., higher temperature, $\mathrm{pH}$ and high salt concentration. Fungal laccase generally fails to work in these extreme environments. ${ }^{3,4}$ Moreover, bacterial laccases have some additional advantages because of their cost-effective use in industrial applications, which include broad substrate specificity, enzyme production in a short time, thermostability and easy to clone and express in the host with suitable manipulation. ${ }^{5}$

Bacterial laccases are useful in pulp and paper biobleaching, degradation of dyes, textile industry, pollutant degradation and biosensor development. ${ }^{6}$ Laccase is a substrate-specific enzyme and in general, it oxidizes a wide range of substrates such as phenolic compounds, phenylpropanoids, azo dyes and indigo dyes. ${ }^{7}$ Phenolic compounds such as hydroquinone and catechol are good substrates for the majority of laccases; moreover, methoxy-substituted phenolic compounds, syringaldazine, guaiacol and DMP (2,4-di-methoxy phenol) are commonly used substrates. ${ }^{8}$

There are two types of laccases, true laccase and false laccase. Laccase which shows activity with tyrosine is called false laccase and that which does not show activity is called true laccase. Till date, blue laccase is the most studied one in comparison to yellow or white laccase. ${ }^{9}$ First, bacterial laccase from rice rhizosphere was isolated in the year 1993, known as Azospirillum lipoferum. ${ }^{10}$ Laccase producing bacteria are of mainly Gram positive. e.g., Bacillus, Geobacillus, Streptomyces, Rhodo coccus, Staphylococcus, Azospirillum, Lysini bacillus and Aquisali bacillus. ${ }^{11}$ However, some Gram-negative bacteria like Pseudomonas, Enterobacter, Delfia, Proteobacterium and Alteromonas are also able to secrete laccase. ${ }^{12}$ 
Laccase has become an important industrially relevant enzyme that has a wide range of applications such as delignification of lignocellulosic material, bioremediation applications such as waste detoxification.

Lignocellulose is the organic compound which comprises about $95 \%$ of land based biomass produced by plants. Lignin forms tight association with cellulose and hemicelluloses to form lignocelluloses as a rigid recalcitrant material in woody plants. ${ }^{13}$ However, one of the limitations for the large-scale application of laccase is the lack of capacity to produce large volumes of the highly active enzyme at an affordable cost. The use of inexpensive sources for laccase production is being explored in recent times. In this regard, an emerging field in the management of industrial wastewater is exploiting its nutritive potential for the production of laccase. Hence an attempt has been made to isolate novel laccase producing bacteria from contaminated soil.

\section{MATERIALS AND METHODS}

\section{Chemicals and reagents}

ABTS (2, 2'-Azino-bis, 3-ethylbenzthiazoline-6-sulfonic acid), Guaiacol and other reagents were procured from $\mathrm{Hi}$ Media Laboratories, Mumbai, India and were of analytical grade.

\section{Collection of samples}

Soil samples containing sawdust and dairy effluents were collected from around the saw mills and Sangam dairy plant in Guntur district, Andhra Pradesh, India. The collected samples were transferred to the laboratory in a pre-sterilized self-sealed polybags and stored at $4^{\circ} \mathrm{C}$. These soil samples were used for screening and isolation of Laccase producing bacteria.

\section{Isolation and screening of laccase producing bacterial} strain

Isolation and screening were carried out by using the method described by Kuddus et al (2013). ${ }^{14}$ 10grams of collected sample was transferred to $100 \mathrm{ml}$ of nutrient broth supplemented with $0.2 \mathrm{mM} \mathrm{CuSO}_{4}$ and $2 \mathrm{mM}$ Guiacol in $250 \mathrm{ml}$ Erlenmeyer flask and incubated at $37^{\circ} \mathrm{C}$ for $48 \mathrm{hrs}$ on a rotary shaker(150rpm). By using standard serial dilution plate technique bacterial colonies were isolated from nutrient agar medium containing $0.2 \mathrm{mM} \mathrm{CuSO}_{4}$ and $2 \mathrm{mM}$ Guiacol and the plates were incubated at $37^{\circ} \mathrm{C}$ for 48 hrs.

Bacterial isolates were primarily screened for laccase production by adding 2-3 drops of $1 \mathrm{mM}$ ABTS laccase substrate to the bacterial isolates. Green colour colonies were identified as laccase producing isolates. These colonies were isolated on to nutrient agar medium containing $0.2 \mathrm{mM} \mathrm{CuSO}_{4}$ and $2 \mathrm{mM}$ Guaiacol. Bacterial isolates were labelled as LP-1,LP-2,LP-3,LP-4,LP-5,LP-6,LP7,LP-8 and LP-9. Further all the bacterial isolates were subjected for secondary screening.
For secondary screening, a loop full of bacterial suspension was inoculated in $50 \mathrm{ml}$ of sterile LB broth supplemented with $1 \%$ fructose and $0.01 \%$ CuSO 4 and incubated at $30^{\circ} \mathrm{C}$ at $125 \mathrm{rpm} .{ }^{15}$ Laccase activity was checked daily by ABTS assay method.

\section{Laccase Activity Assay (ABTS assay)}

Laccase activity was measured using ABTS [2, 2-azino-bis (3-ethylbenzthiazoline-6-sulfonic acid)] substrate for Laccase. The reactive mixture consists of $1.5 \mathrm{ml}$ sodium acetate buffer ( $1 \mathrm{mM}, \mathrm{pH}$ 5.0), $1.5 \mathrm{ml}$ ABTS (0.5 mM) and $1.5 \mathrm{ml}$ cell free supernatant. The absorbance was measured at $420 \mathrm{~nm}$ using UV/Visible Spectrophotometer. ${ }^{16}$ One unit of enzyme activity was defined as 1 micro mole of ABTS oxidized per minute. All the experiments on laccase activity were performed in triplicates.

The laccase activity was calculated as per the following formula:

\section{$E . A=A \times V / t \times e \times v$}

$$
\begin{aligned}
& E . A=\text { Enzyme Activity } \\
& A=A b s o r b a n c e \text { at } \lambda \text { max } \\
& V=\text { Volume of the reaction mixture (in } \mathrm{ml} \text { ), } \\
& t=\text { Incubation time (in min), } \\
& e=\text { Extinction coefficient of the substrate, } \\
& v=\text { Volume of the enzyme extract (in } \mathrm{ml} \text { ). }
\end{aligned}
$$

\section{Morphological and Biochemical characterization of laccase producing bacterial isolates}

High laccase producing bacterial isolates (LP-4 \& LP-8) were examined for morphological and biochemical characteristics with reference to Bergey's Manual of Systematic Bacteriology. Gram's staining and cell morphology of the isolated strains (LP-4 \& LP-8) were performed according to standard protocol. Further, the isolates (LP-4 \& LP-8) were subjected to biochemical tests like Gelatin hydrolysis, Urease, Lipase, oxidase, catalase, nitrate reduction, Indole production, methyl red, VogesProskauer, Citrate utilization and Sugar fermentation.

\section{RESULTS}

\section{Isolation and Screening of Laccase producing bacteria}

Soil samples were collected from contaminated sites and were enriched with nutrient broth medium supplemented with $0.2 \mathrm{mM} \mathrm{CuSO}_{4}$ and $2 \mathrm{mM}$ Guiacol to promote the growth of bacterial strains. For isolation, enriched samples were streaked on nutrient agar medium containing 0.2 $\mathrm{mM}$ CuSO4 and $2 \mathrm{mM}$ Guiacol. All the plates were incubated at $37^{\circ} \mathrm{C}$ for $48 \mathrm{hrs}$. Total 50 different bacterial colonies were isolated and primarily screened for laccase production by adding 2-3 drops of $1 \mathrm{mM}$ ABTS laccase substrate to the bacterial isolates. Green colour colonies were identified as laccase producing isolates. 
Out of 50 isolates, 9 showed Green colour. Green colour colonies were selected and subjected for secondary screening. Selected 9 isolates were subjected to secondary screening by laccase production assay in LB broth supplemented with $1 \%$ fructose and $0.01 \% \mathrm{CuSO}_{4}$ and incubated at $30^{\circ} \mathrm{C}$ at $125 \mathrm{rpm}$. Laccase activity was checked daily by ABTS assay method. The results were shown in Table $1 \& 2$.
Out of 9 bacterial isolates, LP-4 and LP- 8 were selected on the basis of maximum laccase activity of $8.51 \mathrm{U} / \mathrm{ml} \& 9.84$ $\mathrm{U} / \mathrm{ml}$. Further, both bacterial isolates (LP-4 \& LP-8) were tested for morphological and biochemical characterization as per Bergey's manual of Systematic Bacteriology. The results were shown in Table.3, 4 \& 5 .

On the basis of cultural and biochemical characteristics, the bacterial isolates (LP-4 \& LP-8) were identified as Enterobacter sp.\& Bacillus sp. Respectively.

Table 1: Quantitative screening of laccase activity from bacterial isolates: LP-1 to LP-5 (The values are presented as the mean \pm SD of triplicate tests)

\begin{tabular}{|c|c|c|c|c|c|}
\hline Incubation time & $\begin{array}{c}\text { Laccase activity } \\
\text { of LP-1 (U/ml) }\end{array}$ & $\begin{array}{c}\text { Laccase activity } \\
\text { of LP-2 (U/ml) }\end{array}$ & $\begin{array}{c}\text { Laccase activity } \\
\text { of LP-3 } \mathbf{( U / m l})\end{array}$ & $\begin{array}{c}\text { Laccase activity } \\
\text { of LP-4 (U/ml) }\end{array}$ & $\begin{array}{c}\text { Laccase activity } \\
\text { of LP-5 (U/ml) }\end{array}$ \\
\hline Day 1 & $1.91 \pm 0.01$ & $1.22 \pm 0.02$ & $1.44 \pm 0.03$ & $2.2 \pm 0.02$ & $1.32 \pm 0.01$ \\
\hline Day 2 & $2.2 \pm 0.03$ & $1.78 \pm 0.03$ & $1.93 \pm 0.04$ & $3.51 \pm 0.01$ & $1.81 \pm 0.04$ \\
\hline Day 3 & $3.41 \pm 0.02$ & $2.04 \pm 0.01$ & $2.41 \pm 0.03$ & $5.72 \pm 0.02$ & $2.93 \pm 0.02$ \\
\hline Day 4 & $4.92 \pm 0.01$ & $2.52 \pm 0.02$ & $2.93 \pm 0.01$ & $8.51 \pm 0.01$ & $3.91 \pm 0.05$ \\
\hline Day 5 & $4.96 \pm 0.04$ & $3.12 \pm 0.04$ & $3.71 \pm 0.03$ & $8.51 \pm 0.01$ & $4.2 \pm 0.01$ \\
\hline Day 6 & $4.96 \pm 0.04$ & $3.12 \pm 0.04$ & $3.71 \pm 0.03$ & $8.51 \pm 0.01$ & $4.2 \pm 0.01$ \\
\hline
\end{tabular}

Table 2: Quantitative screening of laccase activity from bacterial isolates: LP-6 to LP-9 (The values are presented as the mean \pm SD of triplicate tests)

\begin{tabular}{|c|c|c|c|c|}
\hline Incubation time & $\begin{array}{c}\text { Laccase activity of } \\
\text { LP-6 (U/ml) }\end{array}$ & $\begin{array}{c}\text { Laccase activity of } \\
\text { LP-7 (U/ml) }\end{array}$ & $\begin{array}{c}\text { Laccase activity of } \\
\text { LP-8 (U/ml) }\end{array}$ & $\begin{array}{c}\text { Laccase activity of } \\
\text { LP-9 (U/ml) }\end{array}$ \\
\hline Day 1 & $2.73 \pm 0.01$ & $2.01 \pm 0.03$ & $3.42 \pm 0.02$ & $2.83 \pm 0.02$ \\
\hline Day 2 & $3.56 \pm 0.02$ & $2.93 \pm 0.01$ & $5.81 \pm 0.05$ & $3.56 \pm 0.02$ \\
\hline Day 3 & $4.42 \pm 0.02$ & $3.21 \pm 0.04$ & $8.63 \pm 0.01$ & $5.6 \pm 0.05$ \\
\hline Day 4 & $5.8 \pm 0.01$ & $3.93 \pm 0.01$ & $9.84 \pm 0.03$ & $6.7 \pm 0.02$ \\
\hline Day 5 & $6.02 \pm 0.03$ & $4.02 \pm 0.01$ & $9.84 \pm 0.03$ & $6.9 \pm 0.02$ \\
\hline Day 6 & $6.02 \pm 0.03$ & $4.02 \pm 0.01$ & $9.84 \pm 0.03$ & $6.9 \pm 0.02$ \\
\hline
\end{tabular}

Table 3: Morphological characterization of the bacterial isolates (LP-4 \& Ip-8)

\begin{tabular}{|c|c|c|}
\hline Colony Characteristics & Bacterial Isolate (LP-4) & Bacterial Isolate (LP-8) \\
\hline Colour & yellow & Creamy white \\
\hline Shape & rod & rod \\
\hline Motility & Motile & Motile \\
\hline Grams reaction & $-v e$ & + ve \\
\hline Elevation & Convex & Convex \\
\hline Margin & Entire & Entire \\
\hline
\end{tabular}


Table 4: Biochemical characterization of the bacterial isolates (LP-4 \& LP-8)

\begin{tabular}{|c|c|c|c|}
\hline S. No. & Biochemical test & Bacterial Isolate (LP-4) & Bacterial Isolate (LP-8) \\
\hline 1. & Gelatin hydrolysis & + & - \\
\hline 2. & Urease & - & - \\
\hline 3. & Lipase & - & + \\
\hline 4. & Oxidase & - & + \\
\hline 5. & Catalase & + & + \\
\hline 6. & Nitrate reduction & + & + \\
\hline 7. & Indole Production & + & - \\
\hline 8. & Methyl Red & + & - \\
\hline 9. & Voges-Proskauer & + & - \\
\hline 10. & Citrate Utilization & + & + \\
\hline
\end{tabular}

Table 5: Sugar fermentation profile of bacterial isolates (LP-4 \& LP-8)

\begin{tabular}{|c|c|c|c|c|c|}
\hline S. No. & $\begin{array}{c}\text { Name of the } \\
\text { carbohydrate }\end{array}$ & \multicolumn{2}{|c|}{ Bacterial Isolate (LP-4) } & \multicolumn{2}{c|}{ Bacterial Isolate (LP-8) } \\
\hline 1. & Acid production & Gas production & Acid production & Gas production \\
\hline 2. & Maltose & - & + & + & + \\
\hline 3. & Lactose & - & + & + & + \\
\hline 4. & Sucrose & - & + & - & + \\
\hline 5. & Mannitol & + & + & + & + \\
\hline
\end{tabular}

\section{DISCUSSION}

The enrichment of Laccase producing bacteria was achieved by using nutrient agar medium containing $0.2 \mathrm{mM}$ CuSO4 and $2 \mathrm{mM}$ Guaiacol for 48 hours. Bacterial colonies were isolated by serial dilution method using agar medium containing $0.2 \mathrm{mM} \mathrm{CuSO}_{4}$ and $2 \mathrm{mM}$ Guaiacol as an inducer. The Laccase producing ability was determined by adding 2 3 drops of $1 \mathrm{mM}$ ABTS laccase substrate on to the bacterial colonies and confirmed by appearance of green color formation. Laccase producing bacterial isolates (LP-1 to LP9) were isolated from Guntur district soil, which is showing diversity and capability to utilize various biochemicals during study of biochemical characterization.

\section{CONCLUSION}

Total 9 Laccase producing bacterial isolates were obtained from Guntur district soil using agar medium containing 0.2 $\mathrm{mM}$ CuSO4 and $2 \mathrm{mM}$ Guaiacol. Guaiacol is a responsive substrate for screening the laccase producing bacterial isolates. In this study, 2 potent Laccase producers showing high laccase activity (LP-4 \& LP-8) were identified as Enterobacter sp. \& Bacillus sp. according to morphological and biochemical characterization. The results obtained in the present study indicated that Bacillus $s p$. is a potential strain for laccase production. Further, it is valuable to identify up to species level by molecular identification using a 16S rRNA sequence-based technique for various applications.

\section{REFERENCES}

1. Ryan S, Schnitzhofer W, Tzanov T, Cavaco PA, Gubitz GM, An acid-stable laccase from Sclerotium rolfsii with potential for wool dye decolorization, Enz. Mic. Technol., 2003; 33:766-774.

2. Hakulinen N, Rouvinen J, Three-dimensional structures of laccases, Cell Mol Life Sci.,2015; 72:857-868.

3. Du W, Sun C, Liang J, Han Y, Yu J, Liang Z, Improvement of laccase production and its characterization by mutagenesis, J Food Biochem, 2015; 39:101-108.

4. Wang C, Zhao M, Lu L, Wei Z, Li T, Characterization of spore laccase from Bacillus subtilis WD23 and its use in dye decolorization, Afr J Biotechnol., 2011; 10:2186-2192.

5. Fernandes TAR, Silveira WB, Passos FML, Zucchi TD, Laccases from actinobacteria-what we have and what to expect, Post Mikrobiol, 2014; 4:285-296.

6. Mathews SL, Smithson CE, Grunden AM, Purification and characterization of a recombinant laccase-like multi-copper oxidase from Paenibacillus glucanolyticus SLM1, J Appl Microbiol, 2016; 121:1335-1345.

7. Christopher LP, Yao B, Ji Y, Lignin biodegradation with laccase-mediator systems, Front Energy Res., 2014; 2(12):113.

8. Niladevi KN, Sheejadevi PS, Prema P, Strategies for enhancing laccase yield from Streptomyces psammoticus 
and its role in mediator-based decolorization of azo dyes, Appl Biochem Biotechnol, 2008;151:9-19.

9. Chandra R, Chowdhary P, Properties of bacterial laccases and their application in bioremediation of industrial wastes, Environ Sci Process Impacts, 2015; 17:326-342.

10. Givaudan A, Effosse A, Faure D, Potier P, Bouillant ML, Bally $\mathrm{R}$, Polyphenol oxidase in Azospirillum lipoferum isolated from rice rhizosphere:evidence for laccase activity in non-motile strains of Azospirillum lipoferum, FEMS Microbiol, 1993; 108:205-210.

11. Rezaei S, Shahverdi AR, Faramarzi MA,Isolation, onestep affinity purification, and characterization of a polyextremotolerant laccase from the halophilic bacterium Aquisalibacillus elongatus and its application in the delignification of sugar beet pulp, Bioresour Technol, 2017; 230:67-75.

12. Neifar $M$, Chouchane $H$, Mahjoubi $M$, Jaouani $A$, Cherif A, Pseudomonas extremorientalis BU118: a new salttolerant laccase-secreting bacterium with biotechnological potential in textile azo dye decolourization, Biotech, 2016; 6:107.

13. Hannah L. Woo, Terry C. Hazena, Blake A. Simmons, Kristen M, Enzyme activities of aerobic lignocellulolytic bacteria isolated from wet tropical forest soils: Systematic and Applied Microbiology, 2014; 37 : 60-67.

14. Mohammad Kuddus, Babu Joseph, Pramod Wasudev Ramteke, Production of laccase from newly isolated Pseudomonas putida and its application in bioremediation of synthetic dyes and industrial effluents, Biocatalysis and Agricultural Biotechnology, 2013; 2: 333-338.

15. Avares APM, Cristovao RO, Loureiro JM, Boaventura RAR and Macedo EA, Optimization of reactive textile dyes degradation by laccase-mediator system, J. Chem. Tech. Biotechnol., 2008; 83:1609-1615.

16. Bourbonnais R, Paice MG, Oxidation of non-phenolic substrates: An expanded role for laccase in lignin biodegradation, Fed. Eur. Biochem. Soc., 1990; 267(1):99102.

17. Ye, M., Li, G., Liang, W. Q., Liu, Y. H., Molecular cloning and characterization of a novel metagenome-derived multicopper oxidase with alkaline laccase activity and highly soluble expression, Applied microbiology and biotechnology, 2010; 87(3): 1023-103.

18. Sheikhi F, Ardakani MR, Enayatizamir N, RodriguezCouto $S$, The determination of assay for laccase of Bacillus subtilis WPI with two classes of chemical compounds as substrates, Indian journal of microbiology, 2012; 52(4): 701707.

19. Bugg TD, Ahmad $M$, Hardiman EM, Singh $R$, The emerging role for bacteria in lignin degradation and bioproduct formation, Cur. Opi. Biotechnol., 2011; 22(3):394400.

20. Wang $\mathrm{Cl}$, Zhao M, Li Db, Cui Dz, Lu L, Wei Xd, Isolation and characterization of a novel Bacillus subtilis WD23 exhibiting laccase activity from forest soil, African Journal of Biotechnology, 2010; 9(34):18-25.

21. Palleroni N, Genus I, Pseudomonas, Bergey's manual of systematic bacteriology, 2005; 2: 323-379.

22. Bains J, Capalash N, Sharma P, Laccase from a nonmelanogenic, alkalotolerant $\gamma$-proteobacterium JB isolated from industrial wastewater drained soi, Biotechnology letters, 2003; 25(14): 1155-1159.

Source of Support: The author(s) received no financial support for the research, authorship, and/or publication of this article.

Conflict of Interest: The author(s) declared no potential conflicts of interest with respect to the research, authorship, and/or publication of this article.

For any question relates to this article, please reach us at: editor@globalresearchonline.net New manuscripts for publication can be submitted at: submit@globalresearchonline.net and submit_ijpsrr@rediffmail.com 